\title{
STUDI APLIKASI VACUUM PRELOADING SEBAGAI METODE ALTERNATIF PERCEPATAN PROSES KONSOLIDASI PADA TANAH LEMPUNG LUNAK JENUH AIR: TRIAL GVS PADA PERUMAHAN PANTAI INDAH KAPUK, JAKARTA
}

\author{
Andryan Suhendra ${ }^{1}$; Masyhur Irsyam ${ }^{2}$ \\ ${ }^{1}$ Civil Engineering Department, Faculty of Engineering, Binus University \\ Jl. K.H. Syahdan No. 9, Palmerah, Jakarta Barat 11480 \\ andryan@geosinindo.co.id ; asuhendra@binus.ac.id; \\ ${ }^{2}$ Institut Teknologi Bandung \\ Jl. Ganesha 10, Bandung 40132, Indonesia \\ masyhur.irsyam@yahoo.co.id
}

\begin{abstract}
Vacuum preloading is an alternative method to improve water-saturated soft clay by accelerating the consolidation process. A trial using GVS system was done at Pantai Indah Kapuk residence, Jakarta to investigate the system reliability. Monitoring equipments used include settlement plate to measure the consolidation decrease, piezometer to measure pore water tension, inklinometer to identify the soil direction and lateral movement during the vacuum preloading process, and manometer to measure the vacuum pump pressure. Analytical calculations to estimate the consolidation decrease is done using one-dimensional consolidation theory of Terzaghi. Besides, a numerical analysis is performed by element method up to Plaxis software application. Meanwhile, the monitoring results are achieved using Asaoka theory that estimates the achieved degree of reduction and consolidation. The monitoring results and theoretical analysis indicate that the GVS system included in the vacuum preloading method is quite reliable as an alternative method of consolidation acceleration of water-saturated soft clay.
\end{abstract}

Keywords: water-saturated soft clay, consolidation acceleration, Vacuum Preloading, GVS, Plaxis.

\begin{abstract}
ABSTRAK
Vacuum Preloading merupakan salah satu metode alternatif perbaikan tanah lempung lunak jenuh air melalui percepatan proses konsolidasi. Sebuah trial menggunakan sistem GVS pada perumahan Pantai Indah Kapuk, Jakarta telah dilakukan untuk menginvestigasi keandalan sistem ini. Peralatan monitoring dalam trial ini mencakup settlement plate untuk mengukur penurunan konsolidasi, piezometer untuk mengukur tegangan air pori, inklinometer untuk mengetahui arah dan besar pergerakan lateral tanah selama proses vacuum preloading dan manometer untuk mengukur tekanan pompa vakum. Perhitungan analitis untuk memperkirakan besarnya penurunan konsolidasi dilakukan dengan menggunakan teori konsolidasi satu dimensi dari Terzaghi. Selain itu, analisis numerik dilakukan dengan metode elemen hingga penggunaan software Plaxis. Sedangkan hasil monitoring menggunakan teori Asaoka yang dapat memperkirakan besar penurunan dan derajat konsolidasi yang telah dicapai. Hasil monitoring dan analisis teoritis mengindikasikan bahwa sistem GVS yang termasuk dalam metode vacuum preloading cukup andal sebagai alternatif metode percepatan konsolidasi tanah lempung lunak jenuh air.
\end{abstract}

Kata kunci: Lempung lunak jenuh air, percepatan konsolidasi, vacuum preloading, GVS, Plaxis 


\section{PENDAHULUAN}

Permasalahan penurunan konsolidasi yang cukup besar dalam jangka waktu yang cukup lama merupakan permasalahan klasik yang ditemukan pada tanah lempung lunak yang jenuh air. Tersedia berbagai metode perbaikan tanah yang umumnya diaplikasikan untuk menanggulangi permasalahan ini, diantaranya adalah menggunakan material vertical drain untuk memper-cepat proses konsolidasi. Aplikasi vertical drain harus disertai dengan pemberian beban awal (prabeban) untuk meningkatkan tegangan air pori tanah sehingga proses konsolidasi dapat berjalan. Timbunan dari tanah merupakan material yang umum digunakan sebagai prabeban disamping penggunaan batu dan air.

Pada kondisi tanah dasar berupa tanah lempung yang sangat lunak dengan kemampuan daya dukung yang relatif terbatas, seringkali dijumpai permasalahan berupa kelongsoran pada tanah dasar pada saat pengaplikasian prabeban, sehingga harus melakukan proses penimbunan secara bertahap sesuai dengan kemampuan daya dukung tanah dan seringkali membutuhkan waktu yang lama.

Terkait dengan hal tersebut, pada tahun Kjellman (1952) (Chai et al, 2005) memperkenalkan suatu metode pengganti prabeban dengan cara meletakkan lembaran material kedap air di permukaan tanah dan menyedot air dan udara di sisi dalam lembaran kedap air ini dengan menggunakan pompa vakum, yang dikenal dengan nama vacuum consolidation atau vacuum preloading (Indraratna et al, 2003) (Gambar 1).

Dengan berjalannya waktu, metode ini kemudian semakin banyak digunakan dan dikembangkan di berbagai negara namun masih relatif terbatas penggunaannya di Indonesia.

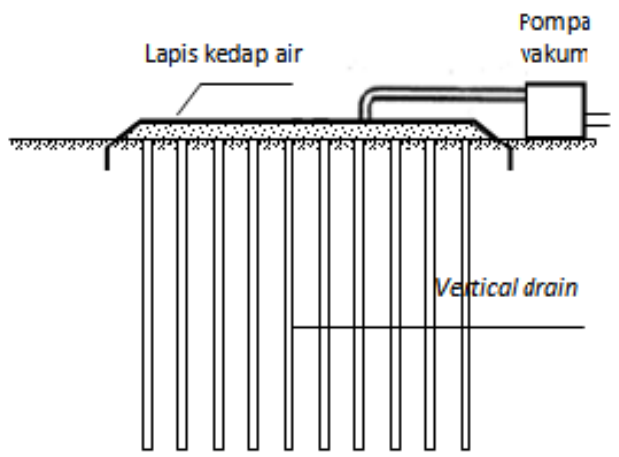

Gambar 1. Ilustrasi aplikasi vacuum preloading.

PT Tetrasa Geosinindo selaku salah satu distributor material geosintetik di Indonesia dengan bekerja sama dengan para ahli dari sektor pendidikan mengembangkan sistem vacuum preloading untuk konsumsi dalam negeri, dan diciptakan suatu sistem dengan nama Geostructure Vacuum System (GVS).

\section{METODE}

Untuk menguji kehandalan GVS, dilakukan uji skala penuh pada area perumahan Pantai Indah Kapuk, Jakarta, seperti yang akan disajikan dalam makalah ini. Sebelum uji skala penuh dilaksanakan, dilakukan penyelidikan tanah lapangan dan pengujian laboratorium untuk mengetahui karakteristik dan properti tanah dasar yang selanjutnya digunakan untuk keperluan prediksi penurunan konsolidasi 
tanah dasar yang akan terjadi akibat beban pompa vakum. Analisis penurunan konsolidasi akan dilakukan menggunakan metode analitis yaitu persamaan konsolidasi 1-D dari Terzaghi (Das, 2006) dan metode elemen (Bergado \& Long, 1993) hingga melalui penggunaan program Plaxis. Pengujian di lapangan mencakup instalasi GVS dan pengamatan terhadap pergerakan tanah baik vertikal maupun horizontal dalam rentang waktu tertentu. Hasil pengamatan ini kemudian akan diolah dan diperbandingkan dengan analisis awal untuk diambil kesimpulan.

\section{HASIL DAN PEMBAHASAN}

\section{Geostructure Vacuum System}

Geostructure Vacuum System atau GVS dikembangkan setelah melalui beberapa percobaan guna mendapatkan hasil yang optimal. Berdasarkan hasil uji coba yang dilakukan pada perumahan Pantai Indah Kapuk, Jakarta, tekanan pompa vakum yang bekerja dapat mencapai $90 \mathrm{kN} / \mathrm{m}^{2}$ yang setara dengan tanah timbunan setinggi $5 \mathrm{~m}$ (asumsi berat volume tanah timbunan $18 \mathrm{~m}$ ). Ilustrasi dari sistem ini seperti terlihat pada Gambar 2 berikut ini.

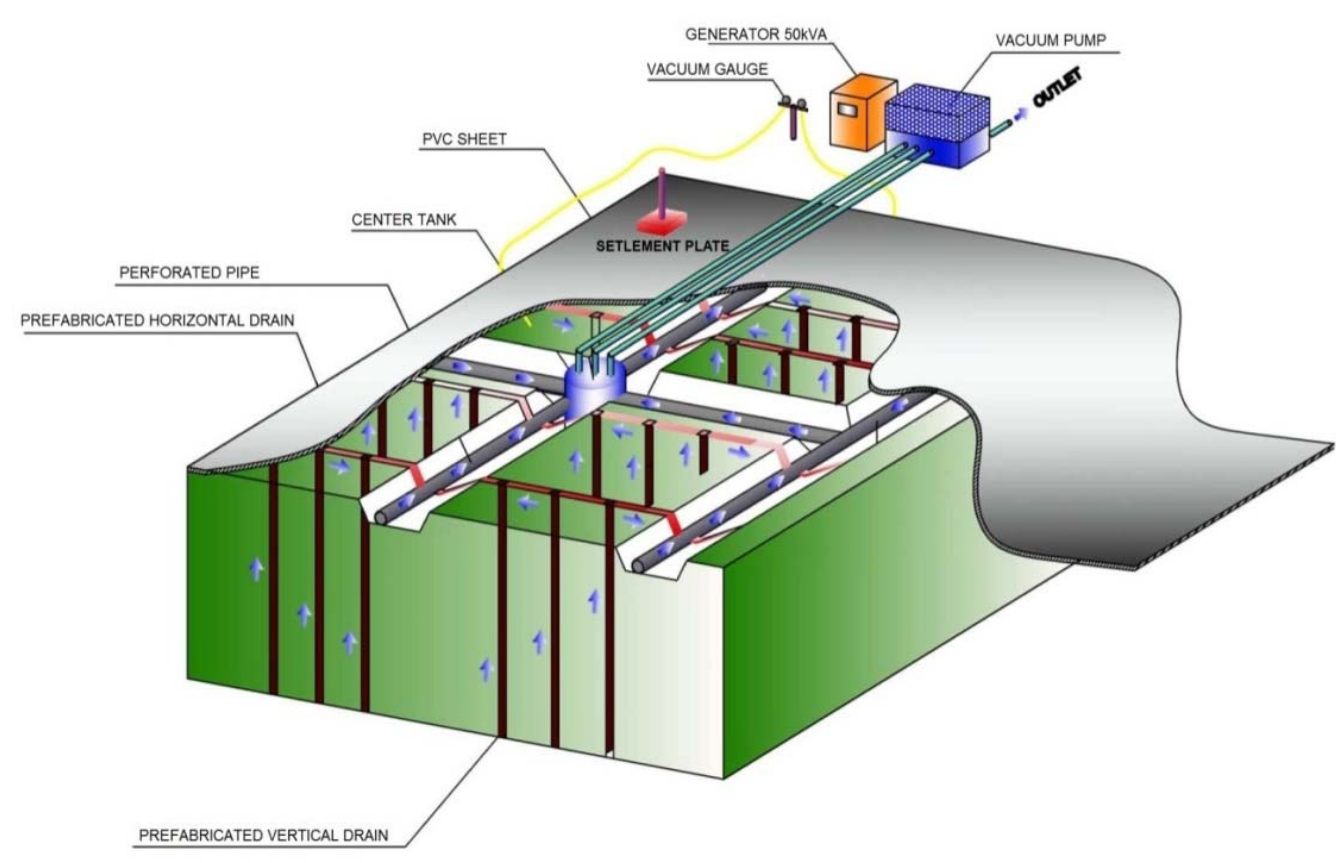

Gambar 2. Geostructure vacuum system.

\section{Kondisi Tanah Pada Lokasi Pengujian}

Sebanyak 2 titik bor yang dilengkapi dengan pengambilan sampel untuk uji laboratorium dan uji SPT serta 5 titik sondir telah dilakukan untuk mengetahui kondisi tanah dasar dan mendapatkan parameter perancangan.

Dari hasil penyelidikan tanah tersebut diperoleh profil tanah dan properti tanah dasar pada berbagai kedalaman seperti ditunjukkan dalam Gambar $3-5$ berikut ini. 


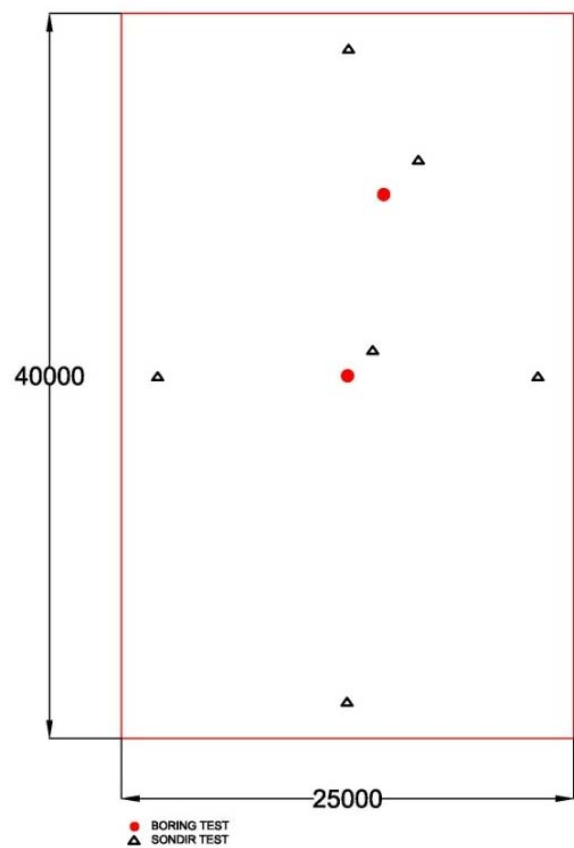

Gambar 3. Titik penyelidikan tanah dasar.

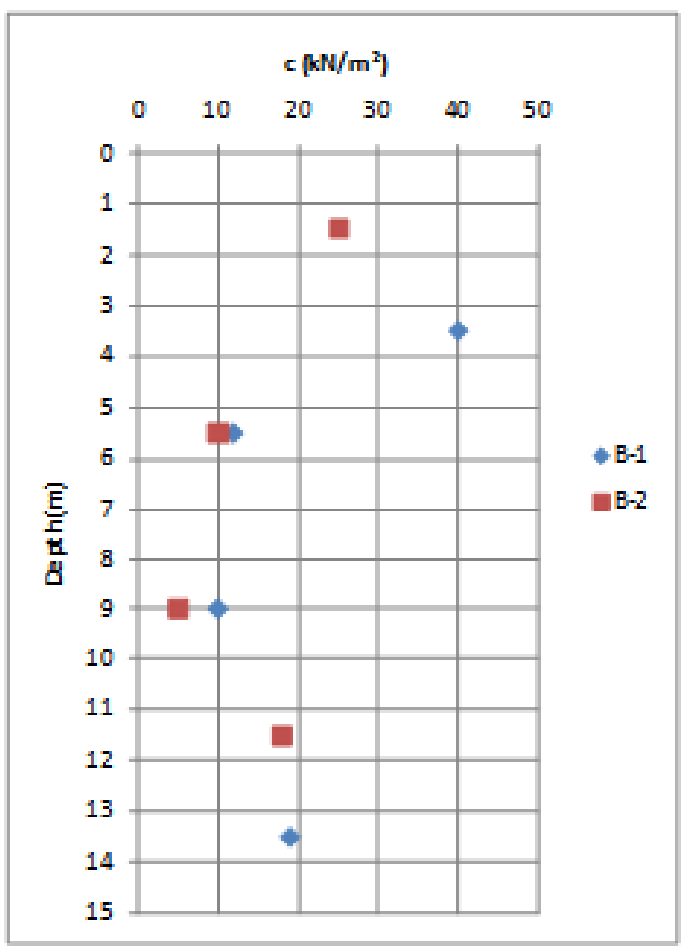

BH-1

BH-2

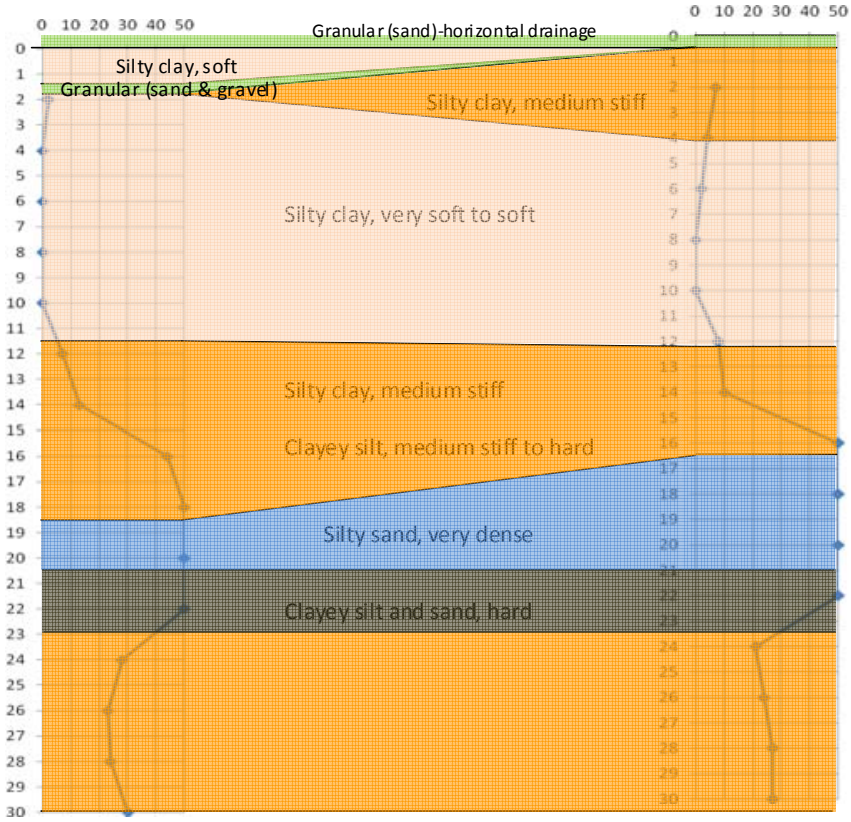

Gambar 4. Profil tanah dasar.

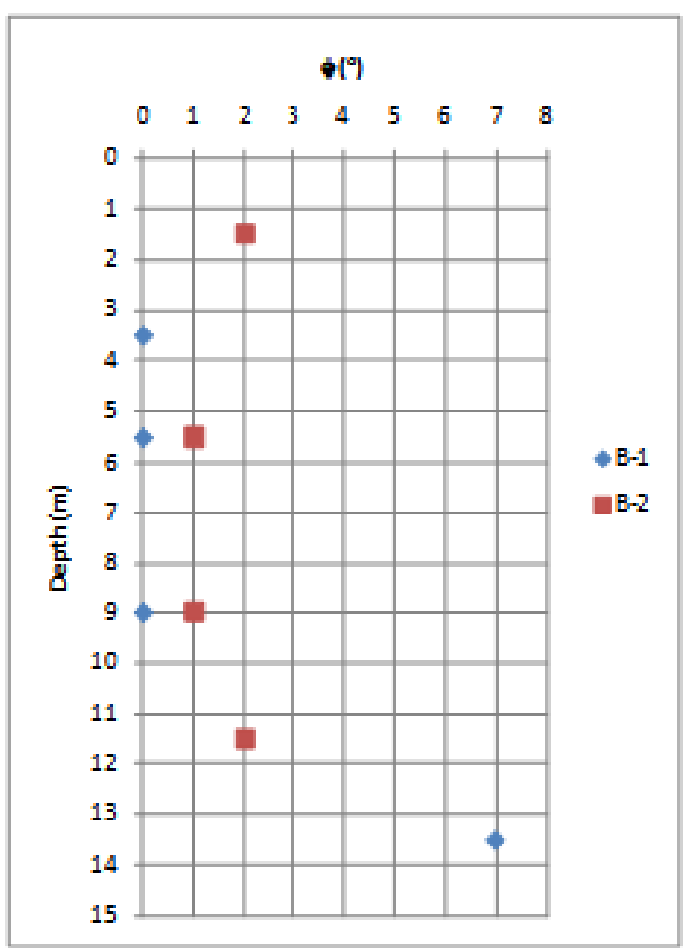



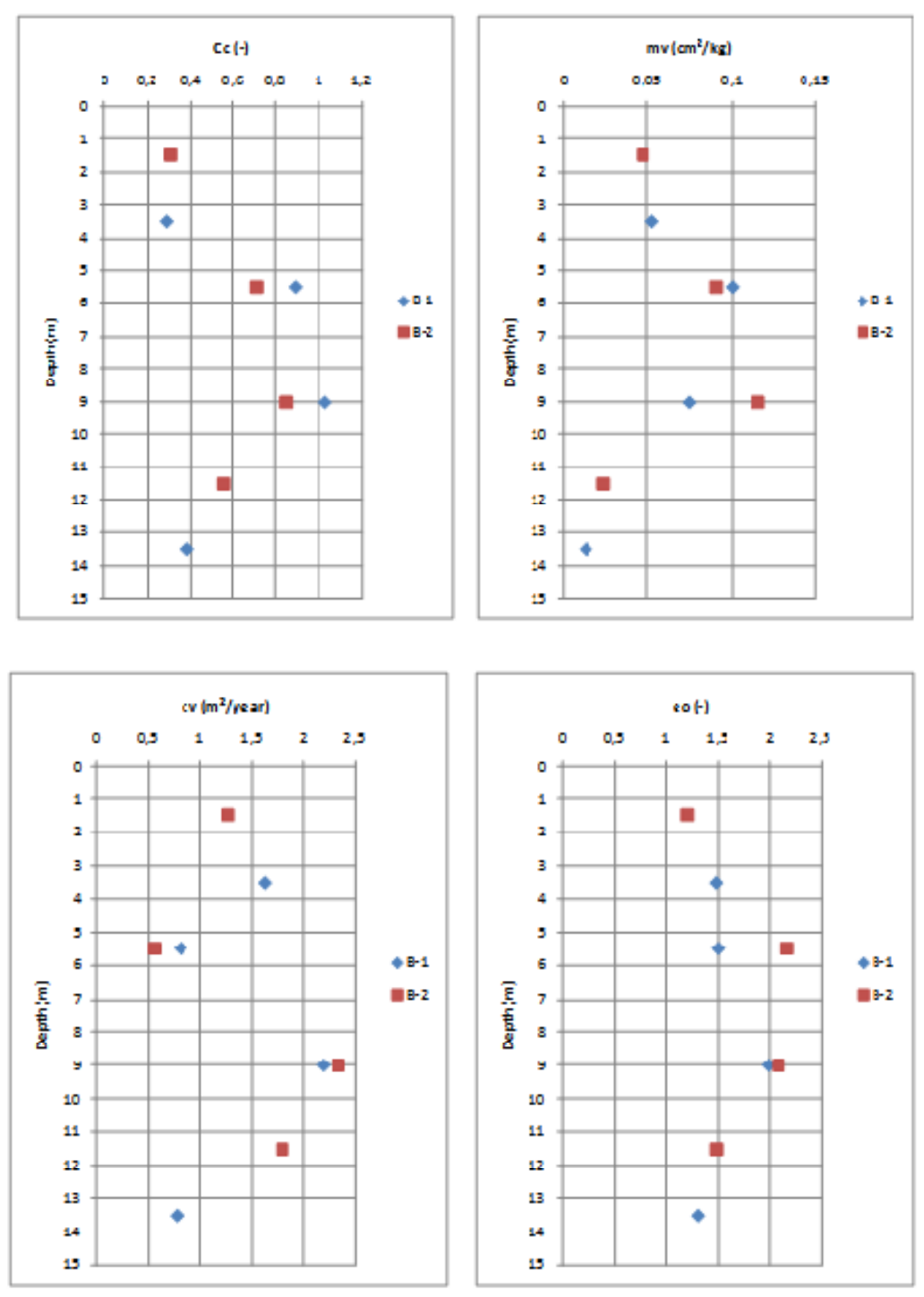

Gambar 5. Parameter tanah dasar.

\section{Analisis Awal}

Analisis awal yang dilakukan adalah perhitungan perkiraan besar dan lama penurunan konsolidasi untuk berbagai variasi beban. Analisis dilakukan dengan menggunakan teori konsolidasi 1 dimensi dari Terzaghi (Das, 2006), yaitu:

$$
\begin{gathered}
S_{c}=\frac{C c}{1+e o} \cdot H_{c} \cdot \log \frac{\sigma_{o}{ }^{\prime}+\Delta \sigma}{\sigma_{o}{ }^{\prime}} \\
t=\frac{T v \cdot H^{2}}{C v}
\end{gathered}
$$

Mengacu pada persamaan tersebut dan berdasarkan data tanah yang tersedia, besar penurunan konsolidasi yang diperkirakan terjadi untuk berbagai variasi beban (Gambar 6). 


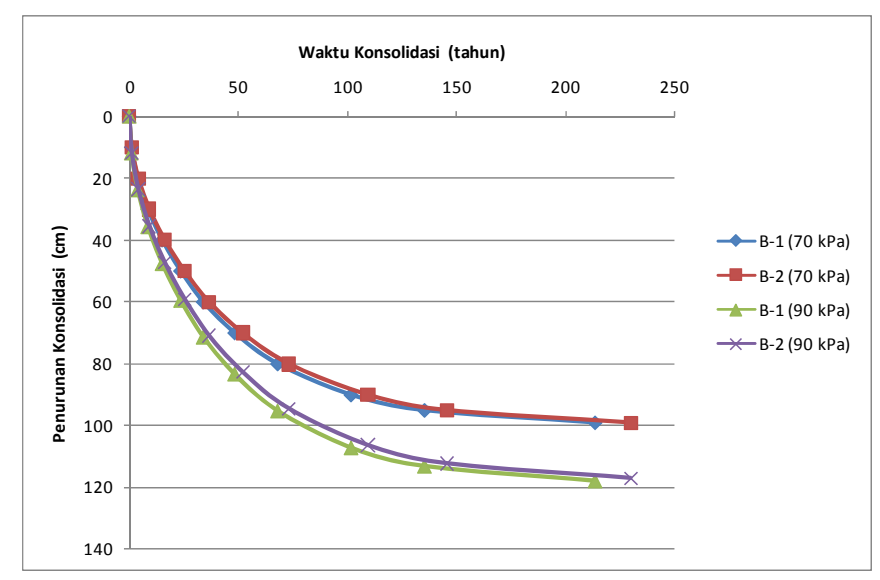

Gambar 6. Prediksi penurunan konsolidasi berdasarkan teori konsolidasi 1-D Terzaghi.

Berdasarkan perhitungan menggunakan metode numerik melalui penggunaan program Plaxis (Shang et al, 1998) diperoleh hasil yang disajikan dalam Gambar 7 dan 8 berikut ini.

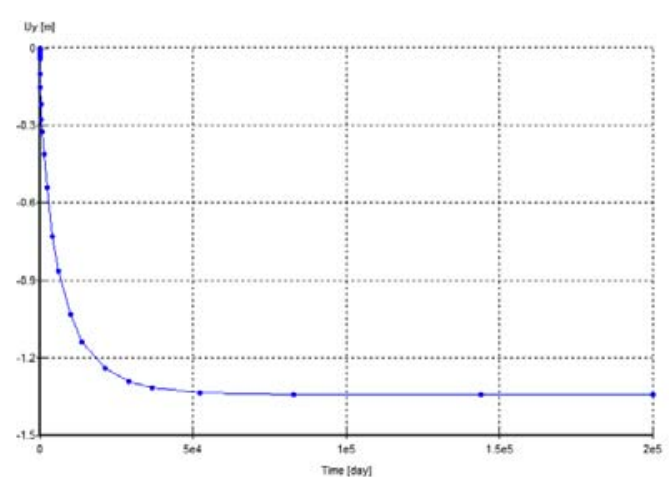

Gambar 7. Prediksi penurunan konsolidasi menggunakan metode numerik.

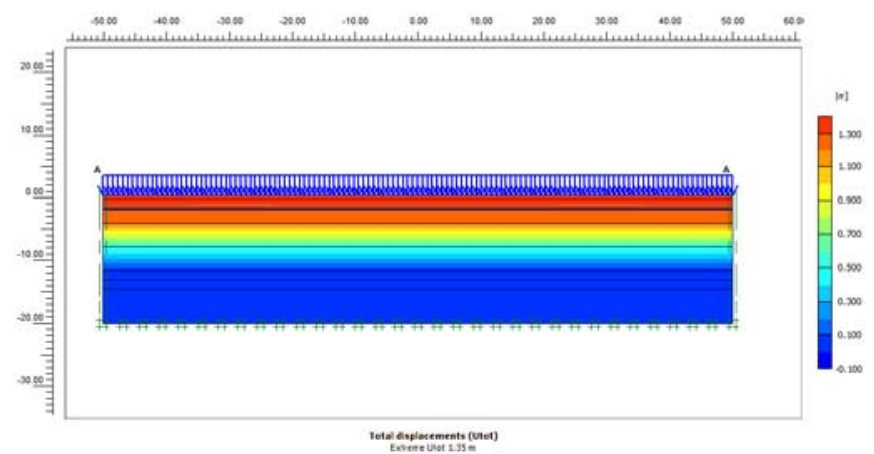

Gambar 8. Konsolidasi hasil output plaxis.

\section{Pelaksanaan Uji Skala Penuh}

Uji skala penuh dilakukan pada perumahan Pantai Indah Kapuk seluas $1000 \mathrm{~m}^{2}$ (25 m x 40 $\mathrm{m})$. Proses pelaksanaan dimulai dari perapihan lahan kerja yang dilanjutkan dengan penghamparan lapis drainase dari pasir setebal $50 \mathrm{~cm}$. Tahap selanjutnya merupakan pemasangan vertical drain sedalam 13,5 m dengan jarak $1 \mathrm{~m}$ (as ke as) pola persegi. Setelah vertikal drain terpasang dilanjutkan dengan penyambungan dengan material horizontal drain yang kemudian disambungkan dengan pipa menuju le pompa vakum. Selanjutnya dilakukan penutupan permukaan dengan menggunakan material kedap air (geomembrane). Setelah semua material terpasang dengan baik dan benar (Gambar 9), proses pengaplikasian pompa vakum mulai dilaksanakan selama 3 bulan tanpa terputus (Gambar 10).

Untuk keperluan pemantauan penurunan yang terjadi serta parameter lain yang perlu dibaca, dilakukan pemasangan alat instrumentasi berupa settlement plate sebanyak 9 buah, inklinometer sebanyak 2 buah, piezometer sebanyak 2 titik pada kedalaman yang berbeda serta manometer untuk mengukur tegangan pompa vakum di bawah lapis kedap air. 


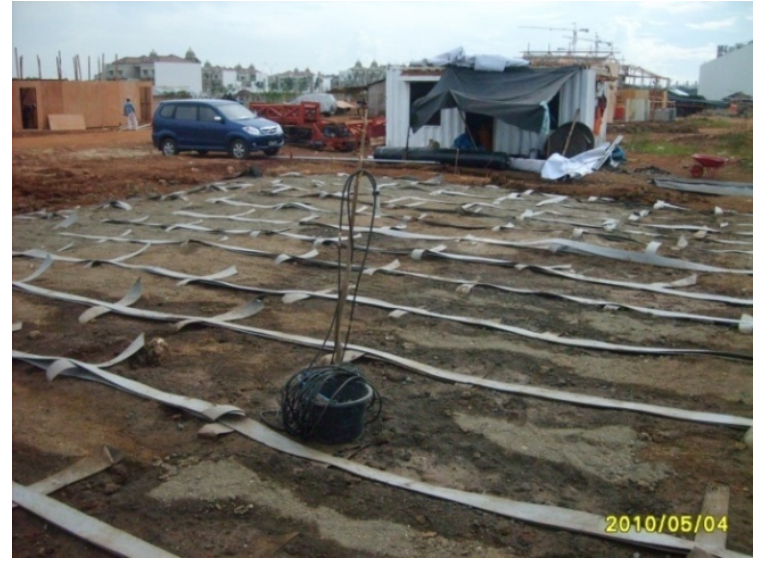

Gambar 9. Pemasangan jaringan GVS.

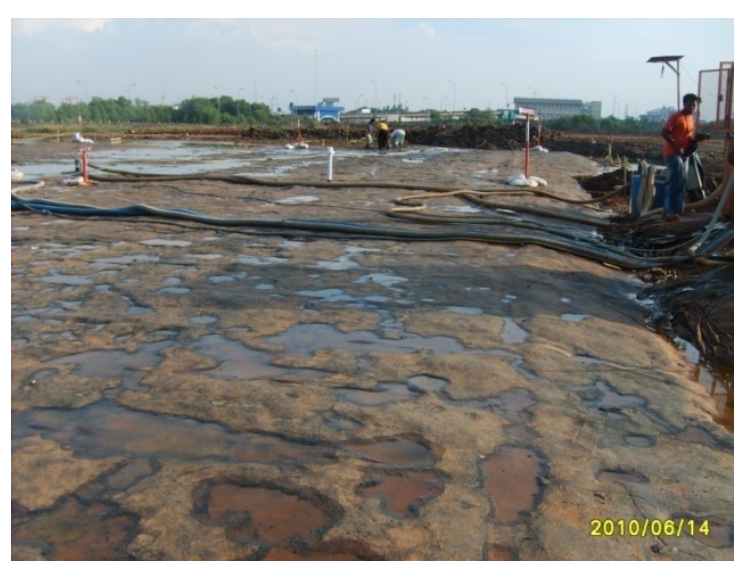

Gambar 10. Proses vakum sedang berlangsung.

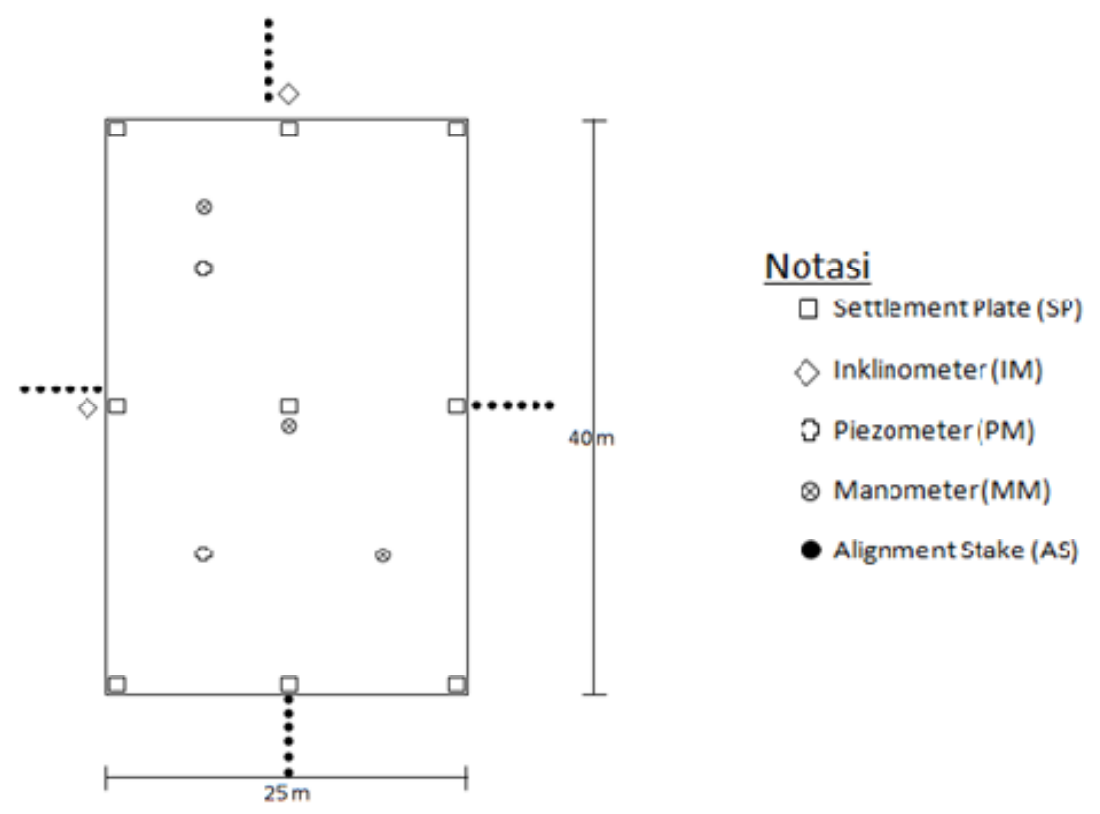

Gambar 11. Posisi alat monitoring.

\section{Hasil Monitoring Uji Skala Penuh}

Hasil pembacaan settlement plate untuk mengetahui besar penurunan konsolidasi yang terjadi disajikan pada Gambar 12 berikut ini yang dilengkapi dengan besar beban vakum yang bekerja. Kinerja dari pompa vakum GVS ditunjukkan oleh pembacaan manometer yang bisa mencapai tekanan $90 \mathrm{kPa}$ (Gambar 13).

Sedangkan untuk pembacaan inklinometer dan piezometer disajikan dalam grafik pada Gambar 14 dan 15 berikut ini. Setelah proses perbaikan tanah selesai dilaksanakan selama 3 bulan, kemudian dilakukan penyelidikan tanah untuk mengetahui kondisi tanah dasar pasca proses vacuum preloading. Salah satu parameter tanah yang menunjukkan adanya peningkatan pasca vacuum preloading ini adalah kuat geser tanah (Gambar 16). 


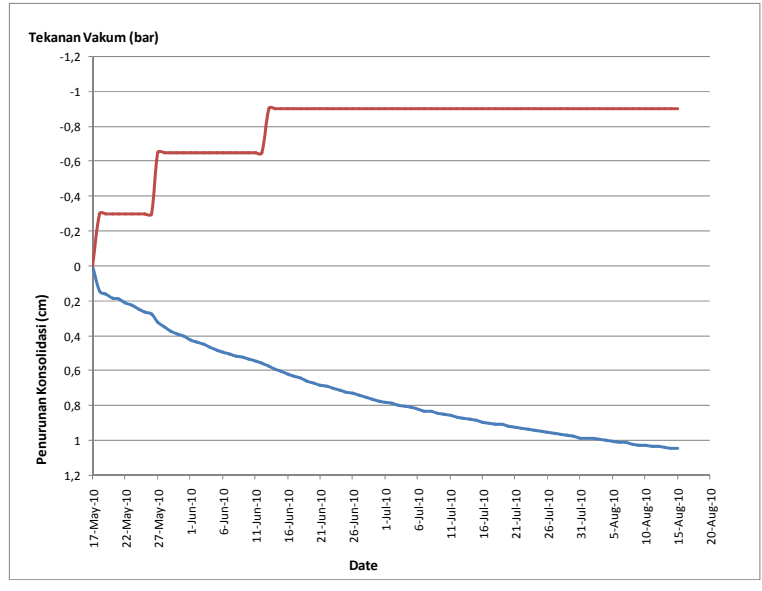

Gambar 12. Hasil pembacaan settlement plate dan tegangan vakum.

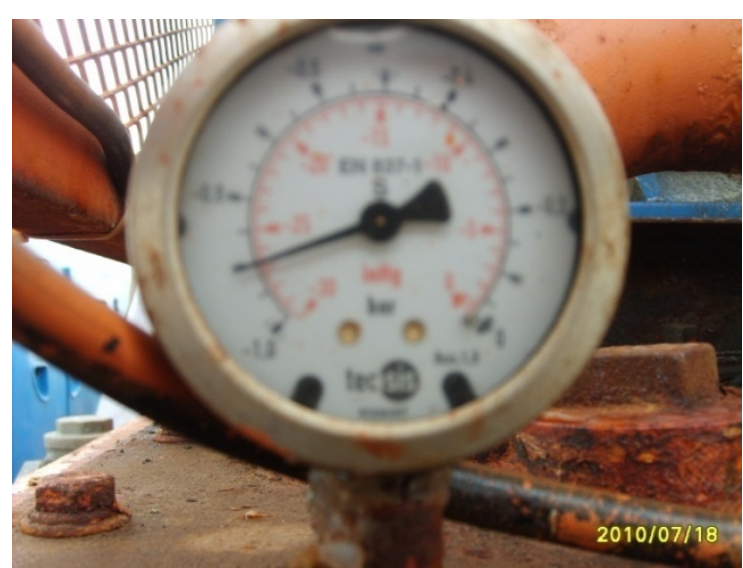

Gambar 13. Bacaan Manometer menunjukkan tegangan vakum mencapai $90 \mathrm{kPa}$.

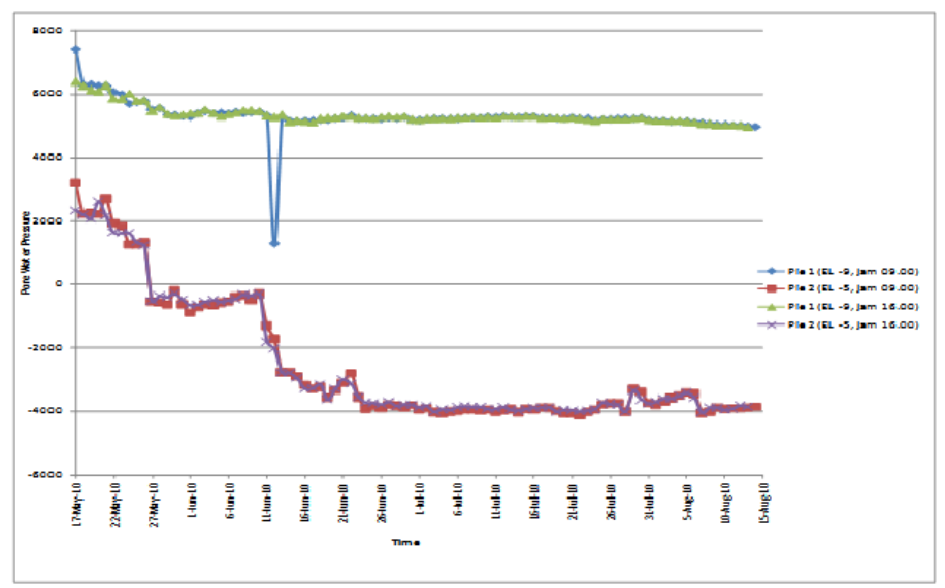

Gambar 14. Hasil pembacaan piezometer.
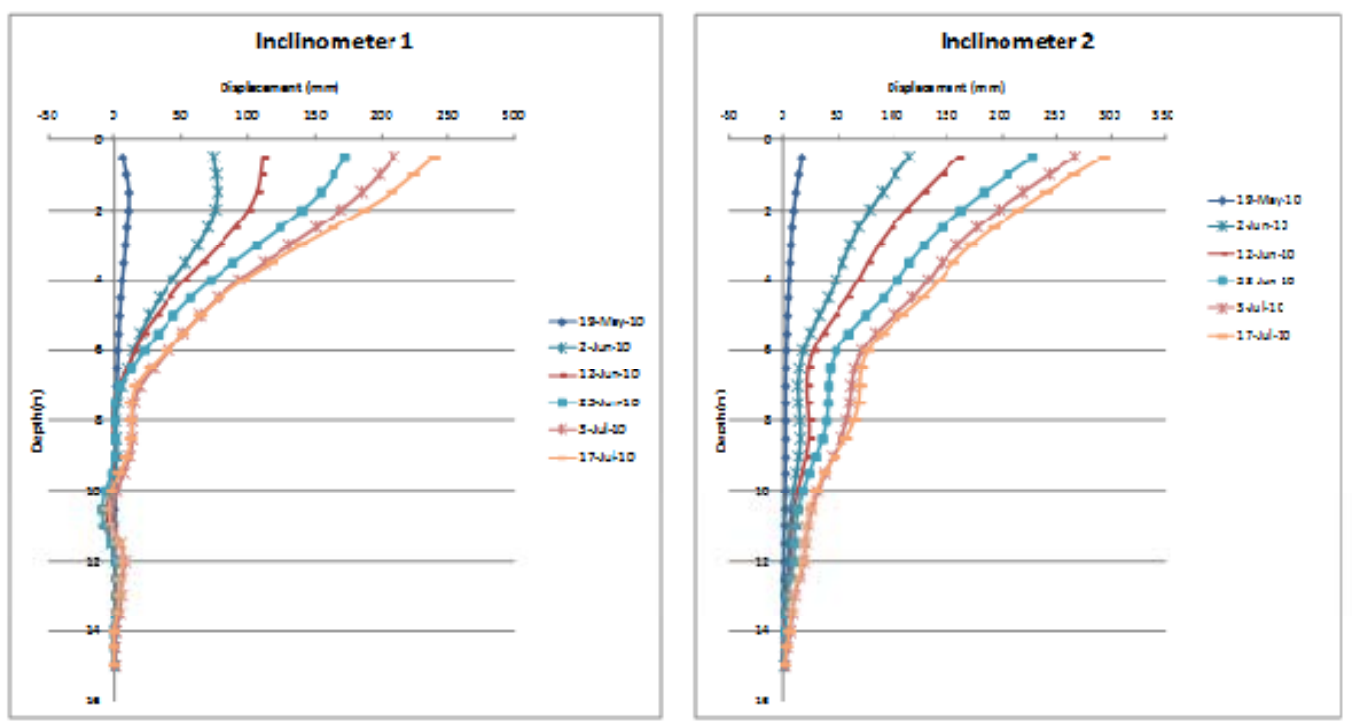

Gambar 15. Hasil pembacaan inklinometer. 


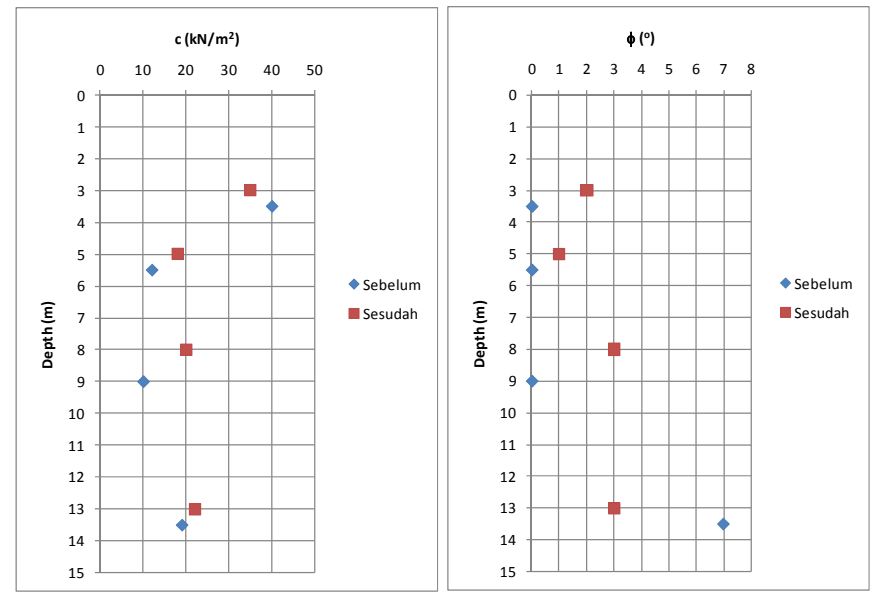

Gambar 16. Kuat geser tanah sebelum dan sesudah uji skala penuh.

\section{Perbandingan Hasil Uji Skala Penuh Dengan Hasil Analisis}

Dari hasil pembacaan settlement plate, kemudian dilakukan analisis balik untuk memperkirakan besar penurunan konsolidasi menggunakan teori dari Asaoka (1978) dengan hasil seperti pada Gambar 17 berikut.

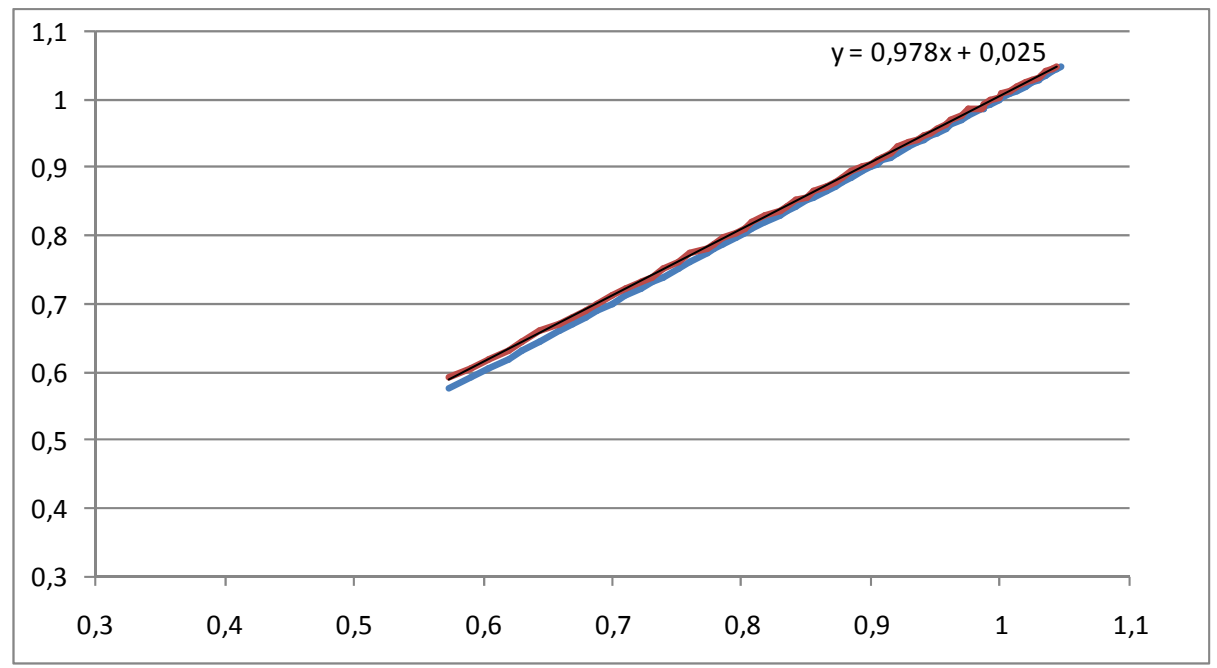

Gambar 17. Perkiraan penurunan konsolidasi total menurut Asaoka.

Mengacu pada Gambar 17, dapat diperkirakan besar penurunan konsolidasi total yang mungkin terjadi melalui penggunaan persamaan

$$
y=0,978 x+0,025
$$

sehingga dapat diprediksi besar penurunan total (derajat konsolidasi 100\%) sebesar 1,14 m.

Gambar 18 berikut ini Grafik merupakan perbandingan penurunan konsolidasi yang terjadi antara hasil analisis dan hasil uji di lapangan. 


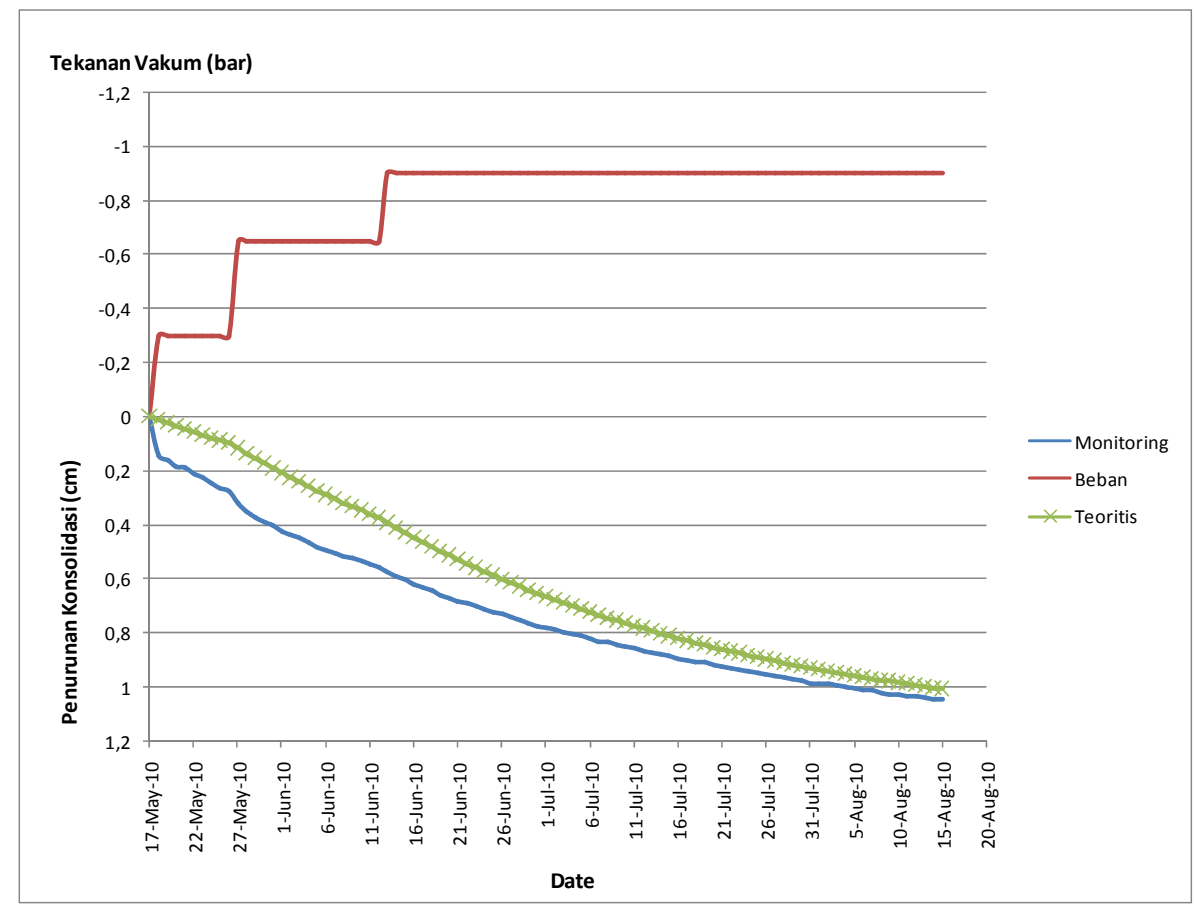

Gambar 18. Perbandingan prediksi penurunan dan hasil monitoring.

\section{PENUTUP}

Beberapa kesimpulan yang dapat disampaikan dari hasil uji skala penuh serta perhitungan analitis dan numerik adalah sebagai berikut: (1) Besar penurunan konsolidasi total berdasarkan perhitungan analitis dan analisis balik hasil pembacaan settlement plate menunjukkan nilai yang hampir serupa yaitu 119,2 cm untuk perhitungan menggunakan metode Terzaghi dan $114 \mathrm{~cm}$ untuk analisis balik menggunakan metode Asaoka. Sedangkan berdasarkan analisis menggunakan metode numerik melalui penggunaan program Plaxis, besar penurunan total sedikit lebih besar yaitu sekitar $130 \mathrm{~cm}$; (2) Besar tekanan pompa vakum GVS sangat efektif yang dapat mencapai $90 \mathrm{kN} / \mathrm{m}^{2}$ setara dengan $5 \mathrm{~m}$ tanah dengan asumsi berat volume tanah $(\gamma)=18 \mathrm{kN} / \mathrm{m}^{3}$, dan bekerja seketika serta kemungkinan terjadi kelongsoran seperti pada sistem prabeban konvensional dapat dihindari; (3) Secara umum terjadi peningkatan kuat geser tanah yang cukup signifikan; (4) berdasarkan hasil perhitungan dan pengamatan di lapangan selama masa uji, Geostructure Vacuum System telah menunjukkan kinerja yang baik sehingga dapat menjadi alternatif solusi perbaikan tanah lempung lunak jenuh air yang mempunyai permasalahan dengan penurunan konsolidasi.

\section{DAFTAR PUSTAKA}

Bergado, D.T., Long, P.V. (1993). Numerical Analysis of Embankment on Subsiding Ground Improved by Vertical Drains. Geotechnical Engineering Bulletin, 2 (3), 177-188.

Chai, J.C., Charter, J.P., Hayashi, S. (2005). Ground Deformation Induced by Vacuum Consolidation. Journal of Geotechnical and Geoenvironmental Engineering (C) ASCE, December 2005.

Das, B.M. (2006). Principles of Geotechnical Engineering, (6th ed.). CL-Engineering 
Indraratna, B., Bamunawita, C., Redana, I., McIntosh, G. (2003). Modelling of Prefabricated Vertical Drains in Soft Clay and Evaluation of Their Effectiveness in Practice. Journal of Ground Improvement, 7(3), 127-138. University of Wollongong.

Shang, J. Q., Tang, M., Miao, Z. (1998). Vacuum Preloading Consolidation of Reclaimed Land: A Case Study, Canadian Geotechincal Journal, 35, 740-749. 